\title{
ChOOSING Club MEMBERShIP UNDER TAX COMPETITION AND FREE RIDING
}

\author{
HYUN PARK \\ APOSTOLIS PHILIPPOPOULOS
}

CESIFO WORKING PAPER NO. 985

CATEGORY 5:Fiscal POLICY, MACROECONOMICS AND GROWTH

JULY 2003

\footnotetext{
An electronic version of the paper may be downloaded

- from the SSRN website:

www.SSRN.com

- from the CESifo website: www.CESifo.de
} 


\title{
ChOOSING Club MEMBERSHIP UNDER TAX COMPETITION AND FREE RIDING
}

\begin{abstract}
We study the choice of club membership, when member-countries' national governments set their tax policies non-cooperatively. Federal policy (in the form of club membership) has a higher constitutional status than national policies (in the form of income tax rates). This allows federal policy to reduce the inefficiencies arising from uncoordinated national policies. We show that equilibrium membership decreases with any factors that generate Nash-type inefficiencies; growing capital mobility is one such factor. In the particular case in which these inefficiencies take the form of tax competition for mobile tax bases and free riding on other countries' contribution to international public goods, one can rationalize the formation of very small economic unions only. The normative result is that union enlargement requires a switch from uncoordinated to coordinated national fiscal policies.
\end{abstract}

Keywords: clubs, capital mobility, federalism.

JEL Code: H2, H7.

\author{
Hyun Park \\ Kyung Hee University Seoul \\ \#1 Hoeki-dong, Dongdaemun-ku, \\ Seoul \\ Korea, 130-701
}

\author{
Apostolis Philippopoulos \\ Athens University of Economics and Business \\ 76 Patission Street \\ Athens 10434 \\ Greece \\ Aphil@aueb.gr
}

We thank seminar participants in Athens, Bern, CESifo in Munich and CSGR at Warwick. We are particularly grateful to Harris Dellas, George Economides, Ben Lockwood, Miltos Makris, Marcus Miller, Thomas Moutos, Efraim Sadka, Hans-Werner Sinn and Peter Birch Sorensen for comments and discussions. Financial support from the Korean Research Foundation (2001-003-C00151) is gratefully acknowledged. All errors are ours. 


\section{INTRODUCTION}

The issue of the formation of clubs is a long-standing question of political economy. ${ }^{1}$ Recently, the theory of clubs has been used to study the issue of the optimal number of nations. ${ }^{2}$ Interest in this topic reflects the changing number of countries in the world (e.g., the breakup of the former Soviet Union into many countries, and the German unification). It also reflects developments in the formation of economic unions or federations (e.g., the European Union, and NAFTA).

An example of a club is the European Union (EU). The general feeling among economists is that EU enlargement is too ambitious. ${ }^{3}$ Economic concerns become stronger given the fact that most national (i.e. domestic) fiscal policies are still selected in a decentralized, uncoordinated way. For instance, national governments in the EU still choose their own tax policies to maximize a domestic objective. ${ }^{4}$ Yet, at the same time, supra-national or federal authorities design institutions and choose common policies to internalize cross-border externalities and promote integration within the union. ${ }^{5}$ A key federal policy is the choice of union membership. What is the "optimal" number of member-countries in an interdependent world where domestic fiscal policies are uncoordinated?

The present paper studies the choice of club membership, when membercountries' national governments set their tax policies non-cooperatively. The setup is a multi-country general equilibrium model with international capital movements and public goods with cross-border externalities. Within this setup, we formalize the choice of national and federal policies. Federal policy (in the form of club membership) is chosen prior to national policies (in the form of income tax rates). In other words, federal policy has a higher constitutional status than national policies. ${ }^{6}$

\footnotetext{
${ }^{1}$ See Cornes and Sandler (1996) for an up-to-date review of the literature on clubs.

${ }^{2}$ See, among others, Bolton and Roland (1997), Alesina and Spolaore (1997), Alesina, Spolaore and Wacziarg (2000) and Alesina, Angeloni and Etro (2001). Details are given in section VI below.

${ }^{3}$ See e.g. Alesina and Wacziarg (1999) and Alesina, Angeloni and Schnuknet (2001) for the EU.

${ }^{4}$ As the economic press argues, "member countries play the nationalist game" (see The Economist, December $8^{\text {th }} 2001$, p. 34).

${ }^{5}$ Thus, the institutional setup is between full decentralization and full federalism. Or what Inman and Rubinfeld (2002) call "democratic federalism". This middle-road system aims to combine the benefits of decentralized federalism with the efficiency advantages of centralized decisions.

${ }^{6}$ As Persson and Tabellini (1996, p. 635) point out, this reflects the EU system and "it captures a situation where the federation has more commitment power and its policy choices are less easily reversible than the national choices". The same authors also say that this is one of the main differences between the "EU" system and the "US" system. In the EU, supranational and national governments are vertically ordered, while in the US they are horizontally ordered.
} 
This hierarchical structure allows federal policy to internalize the behavior of national governments, and hence reduce the inefficiencies arising from uncoordinated national fiscal policies. ${ }^{7}$

At the root of the problem of optimal membership is the tradeoff in the size of population, as studied by the theory of clubs. In the basic model of clubs, ${ }^{8}$ a larger club can benefit from greater economies of scale in the provision of public goods; on the other hand, there are congestion costs when a new member joins. Then, subject to this tradeoff in the size of population, a hypothetical planner chooses club membership to maximize the utility of the representative member. The conceptual difference of our work is that we study how this basic tradeoff in the size of population, and hence the eventual choice of club membership, are affected by the way national fiscal policies are set. ${ }^{9}$ When federal policy chooses club membership, it takes into account that national governments have played the nationalistic Nash game in national tax policies. Equilibrium club membership will therefore reflect this.

Once cross-country interaction is non-cooperative, the type of international spillover effects becomes crucial. Here, we focus on two popular cross-country spillover effects. The first one is generated by international capital mobility coupled with distortionary taxation. As is known, when national policies are non-cooperative, this can lead to tax competition for mobile tax bases. The second spillover effect is generated by the so-called international public goods, i.e. public goods whose benefits extend beyond national boundaries (e.g. security, defense, the environment, health, primary education, infrastructure, etc). As is known, when national policies are noncooperative, this leads to free riding on other countries' contribution to the public good. We choose these two problems (i.e. tax competition and free riding) because they are believed to be important both by the academic literature and the economic press. ${ }^{10}$

Our results are as follows. It is useful to understand first what happens for given membership. Each Nash-type inefficiency (corresponding to a particular spillover effect) ceteris paribus deteriorates with the size of population. Specifically, in our model, the problems of tax competition and free riding each gets worse as the

\footnotetext{
${ }^{7}$ See also Persson and Tabellini (1992) for a model in which voters elect a policymaker before national policymakers choose policy. This timing allows voters to reduce the inefficiencies arising from noncooperative national policies. As the authors say (see p. 698 in their paper), "delegating policy to an agent takes the equilibrium closer to the Pareto frontier of the game".

${ }^{8}$ See e.g. Mueller (1989, chapter 9) and Drazen (2000, chapter 9) for the basic model of clubs.

${ }^{9}$ See section VI below for comparison with the literature.
} 
number of countries increases. ${ }^{11}$ This rather standard result has important implications for the choice of membership.

We then endogenize membership. When a "federal authority" chooses club membership, ${ }^{12}$ it internalizes the tradeoff in the number of countries. On the one hand, a larger size benefits from larger tax bases and revenue contributions needed for the provision of international public goods; this is basically a scale effect from higher membership. On the other hand, in addition to standard congestion problems, the inefficiencies arising from decentralized national policies increase with club size. It is this tradeoff that will determine "equilibrium" membership. We show that equilibrium membership is lower than "efficient" membership. The former corresponds to a case in which membership is chosen subject to a Nash game in national tax policies. The latter corresponds to the benchmark, efficient case in which membership is chosen subject to cooperative national tax policies. ${ }^{13}$

Therefore, to the extent that there are inefficiencies arising from decentralized national policies, equilibrium membership is too low. Intuitively, the federal authority finds it optimal to choose a relatively small membership in order to reduce the degree of Nash-type inefficiencies that naturally increase with the size of population. ${ }^{14}$ This result does not depend on the specific type of inefficiency assumed; any Nash-type inefficiency would give the same result. Therefore, the normative conclusion is that, ceteris paribus, union enlargement requires a switch from uncoordinated to coordinated national fiscal policies.

Numerical simulations confirm our analytical results; namely, equilibrium union membership and national income tax rates are both inefficiently low. The same simulations reveal that equilibrium membership decreases with capital mobility.

\footnotetext{
${ }^{10}$ For the academic literature, see e.g. Persson and Tabellini (1992, 1995), Inman and Rubinfeld (1996), Razin and Sadka (1999), Sorensen (2000) and Devereux, Lockwood and Redoano (2002).

${ }^{11}$ For instance, in the EU, difficulties in getting agreements in the policy areas of structural funds and CAP get worse when the number of member-countries increases.

${ }^{12}$ In our setup, the decision of a federal authority coincides with the decision that it is optimal for the individual citizen-voter (see section IV below).

${ }^{13}$ Thus, the equilibrium outcome is inefficient. Note that the literature on the optimal number of nations has also distinguished "optimal" from "equilibrium" outcomes [see, in particular, Alesina and Spolaore (1997) and Alesina et al. (2001)]. However, in that literature, this has a different meaning: the former refers to the social planner outcome, while the latter usually refers to a democratically chosen number of nations. Instead, in our paper, the number of nations is always chosen by a planner. Thus, the distinction between "equilibrium" and "efficient" outcomes has to do with the way national policies are set. See also section VI below.

${ }^{14}$ Inman and Rubinfeld (1996, pp. 329-331) also argue that by limiting the number of states in a federal economy can be a constitutional way of reducing the inefficiencies that arise within a decentralized federal economy.
} 
Intuitively, the inefficiency associated with the race-to-the bottom for internationally mobile tax bases gets worse when capital mobility, or the size of population, increases. Hence, when capital mobility increases, the federal authority finds it optimal to set an even smaller membership to mitigate the adverse effects of tax competition. Therefore, union membership should decrease with any factors that exacerbate Nash-type inefficiencies; growing capital mobility is one such factor.

Actually, our numerical simulations reveal that equilibrium membership is very close to one (i.e. it is not optimal to form any union). Equilibrium membership remains tied to one even if, for instance, scale effects become stronger or congestion costs fall. ${ }^{15}$ Therefore, to the extent that decentralized national policies lead to tax competition and free riding, it is hard to rationalize the creation of an economic union, not to mention union enlargement. In terms of policy implications, this means that only if countries in Europe start cooperating their tax policies, factors like increasing scale effects, falling congestion costs, etc, can play a role in justifying the EU and its planned enlargement. Cooperation is a precondition to enlargement.

The rest of the paper is as follows. Section II presents a world economy and solves for a competitive equilibrium. Section III solves for national policies. Section IV solves for federal policy in the form of union membership. Section $\mathrm{V}$ presents conclusions and policy lessons. Section VI reviews the related literature. Section VII discusses limitations and extensions. Mathematical details are in an Appendix.

\section{THE MODEL AND WORLD COMPETITIVE EQUILIBRIUM}

Consider a world economy composed of $M$ countries, indexed by $i=1,2, \ldots, M$. The number of countries, $M$, is chosen by a federal authority. ${ }^{16}$ Each country $i$ is

\footnotetext{
${ }^{15}$ By contrast, in the efficient case, it is optimal to form relatively large unions; also, in this case, optimal membership increases when scale effects become stronger or congestion costs fall.

${ }^{16}$ As in the basic model of clubs, we assume that a central or federal authority creates the world from scratch. Alternatively, we could assume that the world economy is composed of $N$ potential members, where $N$ is exogenous and $M \leq N$ is chosen by the central authority. In that case, one has to distinguish between members, $M$, and non-members, $(N-M)$, whenever optimal conditions are derived [see Cornes and Sandler (1996) for the general theory of clubs; see also e.g. Alesina et al. (2001) for an international union model]. We report that we have experimented with richer models like this. For instance, a model with member and non-member countries where non-members' capital stock is a fraction of members' capital stock and where a planner chooses $M$ to maximize the utility of member countries. Since the spirit of our results is unaffected, here we choose to present the simplest possible model specification (of course, quantitative results depend on e.g. the way members and nonmembers differ, the assumed spillovers between members and non-members, whether only members' utility is considered when membership is chosen or whether both members and non-members' utility
} 
populated by a representative private agent and a national government. The private agent consumes and invests at home and abroad, where investment abroad implies a mobility cost. The national government in each country is benevolent and uses income taxes to finance the provision of a public good, whose benefits extend beyond national boundaries. We assume the Source Principle of international taxation, according to which domestic and foreign investors are being taxed at the same rate (this is the principle used in most countries).

\section{1 Informal description of the model and definition of equilibrium}

The sequence of moves is as follows: first, a federal authority chooses club membership; in turn, national governments simultaneously choose their tax policies; finally, private agents make their consumption-investment choices. ${ }^{17}$ We take as given the design of this three-tier hierarchical structure (i.e. federal government, national governments and private sectors), the assigned policy responsibilities, and the sequence of moves.

We will solve the game backwards. Thus, we first solve the last stage. Private agents in each country maximize their lifetime utility by choosing consumption and investment at home and abroad. In doing so, they act competitively by taking prices and policies as given. The solution to this stage will give a World Competitive Equilibrium. This is for any feasible national fiscal policies and any number of countries.

In the second stage, we solve for Nash national tax policies and the associated level of government expenditures. Each national government chooses its own income tax rate by being concerned only about the welfare of its own citizen and by taking as given the income tax rates of other national governments. When national governments choose their tax policies, they take into account the World Competitive Equilibrium of the previous stage. On the other hand, they take the number of countries as given.

\footnotetext{
matters, etc; see Cornes and Sandler (1996)). On the other hand, we realize that all this has to do only with what Alesina et al. (2001) call the "initial, formation stage". There is a second stage, which is about stability of the club. By not distinguishing between members and non-members, we cannot study that second stage (see also section VII below).

${ }^{17}$ See also Yi (1997) for a two-stage structure, where in the first stage players form coalitions, and in the second stage they engage in a non-cooperative game given the coalition structure. Sequential actions are also assumed in the literature on the optimal formation of nations [see e.g. Bolton and Roland (1997), Alesina and Spolaore (1997), Perroni and Scharf (2001) and Alesina et al. (2001)]. Caplan et al. (2000) study different sequential structures and their implications for federal and national policies.
} 
Finally, in the first stage, a federal authority chooses the number of countries (or club membership) to maximize the utility of the representative citizen. In doing so, it takes into account the outcomes of all previous stages. The solution to this problem will give equilibrium membership.

But we also need a benchmark case. As said above, this is defined to be a case in which the federal authority chooses club membership subject to fully cooperative national policies. The solution to this problem will give a Pareto-efficient membership. This case corresponds to the social planner's optimum.

The rest of this section solves the third, last stage of the game, i.e. a world competitive equilibrium for given national policies and the number of countries. ${ }^{18}$

\section{2 Behavior of private agents}

The model is a multi-country version of the model used by Persson and Tabellini (1992). Consider a two-period economy, with one private and one public good, and linear $A K$ production technologies. Each country $i=1,2, \ldots, M$ is populated by a private agent and a national government.

The private agent in country $i$ maximizes utility:

$$
U^{i}=U\left(c^{i}, d^{i} ; H^{i}, M\right)
$$

where $c^{i}$ and $d^{i}$ are private consumption in the first and second period respectively, $H^{i}$ is the international public good from the point of view of country $i$ [see also equation (5f) below], and $M$ is union membership. The utility function is increasing in $c^{i}, d^{i}$ and $H^{i}$, and decreasing in $M$. The negative affect of $M$ captures crowding, or congestion, costs. ${ }^{19}$ Equations like (1) have been widely used in the literature on clubs. ${ }^{20}$ Without loss of generality, we assume an additively separable function of the form $\log c^{i}+d^{i}+v H^{i}-\frac{\lambda M^{2}}{2}$, where the parameter $v>0$ is the weight given to public services, and the parameter $\lambda>0$ measures congestion costs from higher membership. ${ }^{21}$

\footnotetext{
${ }^{18}$ If we assume away the second stage, we are back to the basic model of the literature on clubs.

${ }^{19}$ An increase in the number of countries typically increases the complexity of communication, bargaining and representation [see e.g. Inman and Rubinfeld (1997)].

${ }^{20}$ See e.g. Mueller (1989, pp. 152-4) and Drazen (2000, pp. 393-4). See also Alesina et al. (2000, p. $1282)$ in the literature on the optimal number of nations.

${ }^{21}$ See Persson and Tabellini (1992) and Alesina et al. (2000) for similar functional forms.
} 
The first-period budget constraint of the private agent in each country $i$ is:

$$
c^{i}+k^{i i}+\sum_{j(\neq i)=1}^{M} k^{i j}=e^{i}
$$

That is, private agents start with an exogenous endowment $e^{i}>0$ and then choose how much to consume and how much to invest at home and abroad. Private agents in country $i$ can invest $k^{i i}$ at home in country $i$, and $k^{i j}$ abroad in countries $j$, where $j \neq i$.

The second-period budget constraint of the private agent in country $i$ is:

$$
d^{i}=\left(1-\theta^{i}\right) A^{i} k^{i i}+\sum_{j(\neq i)=1}^{M}\left(1-\theta^{j}\right) A^{j} k^{i j}-\sum_{j(\neq i)=1}^{M} B\left(k^{i j} ; \beta^{i j}\right)
$$

where the parameter $A^{i}$ is capital return in country $i, 0<\theta^{i}<1$ is the income tax rate in $i$, and the function $B\left(k^{i j} ; \beta^{i j}\right)$ captures net mobility costs from investing $k^{i j}$ abroad, i.e. this function is increasing in $k^{i j}$, while the parameter $\beta^{i j}>0$ measures the size of net mobility cost from investing $k^{i j}$ abroad [see also Persson and Tabellini (1992)]. Without loss of generality, we assume $B\left(k^{i j} ; \beta^{i j}\right)=\frac{\beta^{i j}\left(k^{i j}\right)^{2}}{2}$.

Private agents take prices, tax policy, public services and the number of countries as given. Assuming an interior solution, the first-order conditions are (2a)-(2b) and the Euler equations:

$$
\begin{aligned}
& \frac{1}{c^{i}}=\left(1-\theta^{i}\right) A^{i} \\
& \frac{1}{c^{i}}=\left(1-\theta^{j}\right) A^{j}-\beta^{i j} k^{i j} \quad \text { for } j \neq i \text { and } j=1,2, \ldots, M
\end{aligned}
$$

so that (3a)-(3b) imply:

$$
\left(1-\theta^{i}\right) A^{i}=\left(1-\theta^{j}\right) A^{j}-\beta^{i j} k^{i j}
$$


i.e., without uncertainty, net returns are equalized across countries via capital mobility.

\section{3 National government's budget constraint}

Each national government $i$ spends $h^{i}$ on the public good. This is financed by income taxes. Since we use the source principle of international taxation, the national government $i$ taxes domestic and foreign investors at the same rate, $0<\theta^{i}<1$. Thus, the budget constraint of the national government in country $i$ is:

$$
h^{i}=\theta^{i} A^{i} k^{i}
$$

where $k^{i} \equiv\left(k^{i i}+\sum_{j(\neq i)=1}^{M} k^{j i}\right)$ is the capital stock (and the tax base) in country $i$.

\section{4 World Competitive Equilibrium (for given policy and the number of countries)}

We now solve for a World Competitive Equilibrium (WCE). In this equilibrium: (i) all private agents maximize utility; (ii) all constraints are satisfied; (iii) all markets clear. This is for given national policies $\left(\theta^{i}\right)$ and federal policy $(M)$.

Using (2)-(4) above, we have for each country $i$ in a WCE:

$$
\begin{aligned}
& c^{i}=\frac{1}{\left(1-\theta^{i}\right) A^{i}} \\
& d^{i}=\left(1-\theta^{i}\right) A^{i} k^{i i}+\sum_{j(\neq i)=1}^{M}\left(1-\theta^{j}\right) A^{j} k^{i j}-\sum_{j(\neq i)=1}^{M} \frac{\beta^{i j}\left(k^{i j}\right)^{2}}{2} \\
& h^{i}=\theta^{i} A^{i}\left(k^{i i}+\sum_{j(\neq i)=1}^{M} k^{j i}\right)
\end{aligned}
$$

where,

$$
\begin{aligned}
& k^{i i}=e^{i}-\frac{1}{\left(1-\theta^{i}\right) A^{i}}-\sum_{j(\neq i)=1}^{M} k^{i j} \\
& k^{i j}=\frac{\left(1-\theta^{j}\right) A^{j}-\left(1-\theta^{i}\right) A^{i}}{\beta^{i j}}
\end{aligned}
$$


where $(5 \mathrm{a}),(5 \mathrm{~b}),(5 \mathrm{c}),(5 \mathrm{~d})$ and (5e) give respectively the first-period consumption, the second-period consumption, government expenditure on the public good, capital invested at home, and capital invested abroad. This is for each country $i=1,2, \ldots, M{ }^{22}$

To close the world economy, we have to model the international public good, $H^{i}$, in equation (1) above. Following Alesina et al. (2001), we assume: ${ }^{23}$

$$
H^{i} \equiv h^{i}+\gamma \sum_{j(\neq i)=1}^{M} h^{j}
$$

where the parameter $0 \leq \gamma \leq 1$ measures the extent of the benefit country $i$ enjoys from other countries $j \neq i$ providing the international public good. ${ }^{24}$ We assume $0<\gamma<1$, so that country $j$ 's provision of the public good has a lower effect on country $i$ 's utility than $i$ 's own provision of the public good. Note that a positive $\gamma$ can be also thought of as a scale effect [see e.g. Backus et al. (1992)].

We sum up this section. We have solved for a World Competitive Equilibrium (WCE). This is summarized by (5a)-(5f). These equations give a convenient closed-form analytical solution for equilibrium allocations, as functions of national tax rates, $\theta^{i}$, and the number of countries, $M$. In the next section III, national governments will choose tax policy, $\theta^{i}$. The number of countries, $M$, will be chosen in section IV.

\section{DETERMINATION OF NATIONAL TAX POLICIES}

We move on to the second stage of the game and endogenize national policies. National tax rates, $\theta^{i}$, are determined by a Nash game among national governments.

\footnotetext{
${ }^{22}$ Without capital mobility costs, $\beta^{i j}=0$, the WCE would be indeterminate. Specifically, in each country $i$, we would have two equations only, while there are three endogenous variables $\left(c^{i}, k^{i i}\right.$ and $\left.k^{i j}\right)$. This is a known problem when factor returns are exogenous. This is why introducing mobility costs is particularly useful; it gives a well-defined solution for the WCE without complicating the model. Alternatively, Kehoe (1989) assumes that domestic capital is owned only by domestic investors $\left(k^{i j} \equiv 0\right)$. Also, note that the presence of capital mobility costs allows existence of a Nash equilibrium in national tax policies (see the next section below). Without these costs, and with exogenous factor returns, there would be nothing left for national governments to choose (see (3c) above).

${ }^{23}$ See also Backus, Kehoe and Kehoe (1992) and Alesina and Wacziarg (1999) for similar modeling, although the cross-country externalities are on the production side. The main results do not depend on this.

${ }^{24}$ As in Alesina et al. (2001), if $\gamma=0$, the public good is national; if $\gamma=1$, cross-border spillover effects are perfect.
} 
When they choose $\theta^{i}$, benevolent national governments take into account the World Competitive Equilibrium specified above. On the other hand, they take the number of countries, $M$, as given. We will focus on symmetric equilibria in national policies. That is, ex post, $\theta^{i}=\theta^{j} \equiv \theta, c^{i}=c^{j} \equiv c, d^{i}=d^{j} \equiv d, k^{i i}=k^{j j} \equiv k$, etc, where $i \neq j .^{25}$ Focusing on symmetric equilibria is not restrictive for what we want to do, which is to study how incentives affect the choice of club membership, $M$.

\section{1 Uncoordinated (Nash) national tax policies}

Each national government $i$ chooses $\theta^{i}$ to maximize (1) subject to (5a)-(5f) above. In doing so, it takes $\theta^{j}$, where $j \neq i$, as well as $M$ as given. Using (5a)-(5f) into (1), deriving the first-order condition for $\theta^{i}$, invoking symmetry, and assuming existence of an interior solution, we obtain (from now on, we omit countrysuperscripts):

$$
A\left(e-\frac{1}{(1-\theta) A}\right)=v\left[A\left(e-\frac{1}{(1-\theta) A}\right)-\frac{\theta}{(1-\theta)^{2}}-\frac{2 A^{2} \theta(M-1)(1-\gamma)}{\beta}\right]
$$

which is an equation in $\theta$ only. Then, (6) implies:

Result 1: Given the number of countries, $M$ : (i) A Symmetric Nash Equilibrium (SNE) in national policies is summarized by the tax rate that solves equation (6). (ii) This Nash tax rate, denoted as $0<\widetilde{\theta}<1$, is unique. Also, $\widetilde{\theta}=\theta\left(\vec{M} ; \stackrel{+}{\beta}, \stackrel{+}{\gamma},{ }_{\nu}^{+}, \stackrel{+}{e}\right)$.

\section{Proof: See Appendix.}

Notice that the Nash tax rate decreases with the number of countries, $M$, and increases with capital mobility costs, $\beta$. As we discuss in subsection III.3 below, these are intuitive results.

\footnotetext{
${ }^{25}$ In a symmetric equilibrium, there are no capital flows across countries ex post [see (5e)]; this is as in Persson and Tabellini (1992).
} 


\section{2 Coordinated national tax policies}

It is useful for what follows in the next section to solve also for the case in which national tax policies are chosen cooperatively. Now, a hypothetical planner chooses all $\theta^{i}$ to maximize the sum of (1) over all countries by taking $M$ as given.

Working as above, it is straightforward to show that in Symmetric Cooperative Equilibrium (SCE), we have instead of (6):

$$
A\left(e-\frac{1}{(1-\theta) A}\right)=v[1+\gamma(M-1)]\left[A\left(e-\frac{1}{(1-\theta) A}\right)-\frac{\theta}{(1-\theta)^{2}}\right]
$$

which is an equation in $\theta$ only. Then, (7) implies:

Result 2: Given the number of countries, $M$ : (i) A Symmetric Cooperative Equilibrium (SCE) in national policies is summarized by the tax rate that solves equation (7). (ii) This cooperative tax rate, denoted as $0<\theta^{*}<1$, is unique. Also, $\theta^{*}=\theta(\stackrel{+}{M} ; \stackrel{+}{\gamma}, \stackrel{+}{v}, \stackrel{+}{e})$.

Proof: See Appendix.

Notice that the cooperative tax rate is increasing in the number of countries, $M$, and is unaffected by capital mobility costs, $\beta$. That is, the comparative static properties in Result 2 differ from those in Result 1. Results are explained in the next subsection.

\section{3 Properties of national tax policies}

Inspection of equations (6) and (7) reveals:

Proposition 1: Given the number of countries, $M$ : (i) Since there are cross-country spillover effects, there are typical inefficiencies when national fiscal policies are uncoordinated (Nash). (ii) Ceteris paribus, each Nash-type inefficiency (corresponding to a particular spillover effect) deteriorates with the size of population, M. (iii) Since, in this model, all spillover effects generate positive policy externalities and hence pull the Nash strategies in the same direction, Nash strategies 
are inefficiently low, $0<\widetilde{\theta}<\theta^{*}<1$, and the overall inefficiency increases monotonically with $M$.

These rather standard properties will have interesting implications for the choice of $M$ in the next section. As is discussed below, what is important to our final results will be properties (i) and (ii).

The rest of this subsection explains the above proposition, in case it is not clear. We start with properties (i) and (ii). Recall that there are two spillover effects: international capital movements and international public goods. Irrespectively of whether these spillovers generate positive or negative externalities (see next paragraph), each Nash-type inefficiency (associated with a particular spillover) deteriorates ceteris paribus with the size of population. ${ }^{26}$

Property (iii) arises simply because both spillover effects work in the same direction generating a positive policy externality. A positive externality means that there is a positive external welfare effect from country $j$ 's tax rate to country $i$ 's welfare, where $i \neq j$. Specifically, in the case of international capital movements, an increase in the foreign tax rate leads to capital flight, and hence higher economic growth in the domestic country. In the case of international public goods, an increase in the foreign tax rate leads to higher tax revenues abroad, and hence higher contribution to the provision of international public goods, which again increases domestic welfare. Then, since all policy externalities are positive: (a) The Nash tax rate is unambiguously lower than the cooperative tax rate; i.e. $0<\widetilde{\theta}<\theta^{*}<1$ (see proof of Result 2 in the Appendix). (b) The Nash tax rate decreases monotonically with the size of population, $M \cdot{ }^{27}$ Notice that, by contrast, the cooperative tax rate, $\theta^{*}$, increases with

${ }^{26}$ Observe the last term on the right-hand side of (6), $\frac{2 A^{2} \theta(M-1)(1-\gamma)}{\beta}$, which is absent from (7). This captures tax competition in the absence of cooperation. Then, for $M>1, \widetilde{\theta}$ differs from $\theta^{*}$, and this difference increases ceteris paribus with $M$. The same applies to spillovers from international public goods. Now we have $v$ in (6) instead of $v[1+\gamma(M-1)]$ in (7). This captures free riding. Again, for $M>1, \widetilde{\theta}$ differs from $\theta^{*}$, and this difference increases ceteris paribus with $M$. For the generality of these results, see point (b) in the next footnote.

${ }^{27}$ Our results are consistent with general results for symmetric equilibria. Specifically: (a) In the presence of positive (resp. negative) externalities, players' strategies are inefficiently low (resp. high) in a Nash equilibrium relative to a cooperative one. See e.g. Cooper and John (1988). (b) Ceteris paribus, each Nash-type inefficiency gets worse with the size of population. Thus, when a Nash strategy is inefficiently low (resp. high), it decreases (resp. increases) with the size of population. See e.g. Kehoe (1987) and Philippopoulos and Economides (2003). Note that the relation between the size 
$M$. This happens because cooperative policies are not affected by Nash-type inefficiencies and, at the same time, internalize the positive, scale effects from public good provision [see (5f) above]. All this means that, while the Nash tax rate is decreasing in $M$, the cooperative tax rate is increasing in $M$ [see also Alesina and Wacziarg $\left(1999\right.$, p.20)]. ${ }^{28}$ It also means that tax competition and free-riding pull the Nash tax rate, $\widetilde{\theta}$, in the same direction, so that the degree of overall inefficiency, arising from decentralized national policies, unambiguously increases as $M$ increases. $^{29}$

\section{4 Summarizing results}

At this stage, it is useful to organize algebraic results. We have solved for a Symmetric Nash Equilibrium (SNE) and a Symmetric Cooperative Equilibrium (SCE) in national policies. Specifically, in a SNE, the tax rate is given by (6); in a SCE, the tax rate is given by (7). In turn, (5a)-(5f) imply the resource allocation:

$$
\begin{aligned}
& c=\frac{1}{(1-\theta) A} \\
& d=(1-\theta) A\left(e-\frac{1}{(1-\theta) A}\right) \\
& H=[1+\gamma(M-1)] A\left(e-\frac{1}{(1-\theta) A}\right) \theta
\end{aligned}
$$

Therefore, equations (6) and (8a)-(8c) characterize a Symmetric Nash Equilibrium (SNE) in national policies, while equations (7) and (8a)-(8c) characterize

\footnotetext{
of population and Nash strategy is unambiguous because we have solved for symmetric equilibria. In cases with asymmetric equilibria, results are ambiguous [for a survey, see Myles (1995, pp. 284-7)].

${ }^{28}$ For analogous reasons, $\widetilde{\theta}$ is increasing in capital mobility costs $\beta$ (see Result 1), while $\theta^{*}$ is independent of $\beta$ (see Result 2). Intuitively, the smaller is $\beta$, the higher is the elasticity of capital movements with respect to tax rate differentials, and the fiercer is the competition for mobile tax bases through tax cuts. This is a standard result in the literature on tax competition [see e.g. Persson and Tabellini (1995)]. By contrast, cooperative policies are not affected by such Nash-type inefficiencies, so that $\theta^{*}$ is independent of $\beta$. Also, notice that when $\gamma=1$, i.e. in the limiting case in which international spillovers from public good provision are perfect [see (5f)], the Nash-type inefficiency due to tax competition vanishes in (6) [see also Bjorvatn and Schjelderup (2000)]. However, this does not mean that Nash and cooperative policies coincide. Even when $\gamma=1$, there are still inefficiencies due to free riding [compare (6) and (7)].

${ }^{29}$ If $\beta \rightarrow \infty$ (i.e. there are huge mobility costs so that capital mobility is practically impossible and tax competition does not arise) and $\gamma=0$ (i.e. the public good is only local so that there is no free riding behavior), Nash-type inefficiencies vanish. See (6) and (7) above.
} 
a Symmetric Cooperative Equilibrium (SCE) in national policies. This is for any number of countries, $M$. The next section will endogenize $M$.

\section{DETERMINATION OF CLUB MEMBERSHIP}

We now turn to the first stage of the game, in which a federal authority chooses $M$ to maximize the utility of the representative citizen (since we have solved for a symmetric equilibrium, this coincides with the decision that it is optimal for the individual citizen-voter). ${ }^{30}$ In doing so, the federal authority takes into account all previous stages. As said above, we will distinguish two cases: the equilibrium case in which $M$ is chosen subject to Nash national tax policies, and the Pareto-efficient case in which $M$ is chosen subject to coordinated national tax policies; where the latter case will serve as a benchmark.

\section{1 Equilibrium membership}

The federal authority chooses $M$ to maximize (1) subject to the Symmetric Nash Equilibrium in national tax policies. Specifically, it chooses $M$ to maximize $\log c+d+v H-\left[\lambda(M)^{2}\right] / 2$ where $c, d$ and $H$ are given by (8a), (8b) and (8c) respectively, and the tax rate $\widetilde{\theta}$ is given by (6). The first-order condition gives:

$$
\begin{aligned}
v \gamma \tilde{\theta} A\left(e-\frac{1}{(1-\widetilde{\theta}) A}\right)= & \lambda M- \\
& -v(M-1)\left[\frac{2 A^{2} \widetilde{\theta}(1-\gamma)}{\beta}+\gamma\left(A\left(e-\frac{1}{(1-\widetilde{\theta}) A}\right)-\frac{\tilde{\theta}}{(1-\widetilde{\theta})^{2}}\right)\right] \frac{\partial \widetilde{\theta}}{\partial M}
\end{aligned}
$$

which says that the marginal benefit of $M$ (the left-hand side of (9)) equals the marginal cost of $M$ (the right-hand side of (9)). In our model, the marginal benefit is basically a scale effect: all member-countries benefit from a larger union since this increases the tax base and contributions to the provision of the international public

\footnotetext{
${ }^{30}$ See also e.g. Park and Philippopoulos (2003).
} 
good. ${ }^{31}$ The marginal cost consists of crowding problems ( $\left.\lambda M\right)$, plus efficiency costs due to non-cooperative policymaking at national level (see the second term on the right-hand side and recall that $\frac{\partial \widetilde{\theta}}{\partial M}<0$ in Result 1 above).

Equations (6) and (9) are two equations in $\theta$ and $M$. Let us denote their solution as $\widetilde{\theta}$ and $\tilde{M}$. In other words, (6) and (9), jointly with (8a)-(8c), characterize a world equilibrium in which the federal authority chooses union membership optimally, given that national governments have chosen their fiscal policies noncooperatively.

\section{2 Pareto-efficient membership (benchmark case)}

Now, the federal authority chooses $M$ to maximize (1) subject to the Symmetric Cooperative Equilibrium in national tax policies. Specifically, it chooses $M$ to maximize $\log c+d+v H-\left[\lambda(M)^{2}\right] / 2$, where $c, d$ and $H$ are given by (8a), (8b) and (8c) respectively, and the tax rate $\theta^{*}$ is given by (7). The first-order condition gives:

$$
v \gamma \theta^{*} A\left(e-\frac{1}{\left(1-\theta^{*}\right) A}\right)=\lambda M
$$

Inspection of (9) and (10) reveals that in the latter we do not have the second positive term on the right-hand side. This is because in (10) there are no Nash-type problems as in (9).

Equations (7) and (10) are two equations in $\theta$ and $M$. Let us denote their solution as $\theta^{*}$ and $M^{*}$. In other words, (7) and (10), jointly with (8a)-(8c), characterize a world equilibrium in which the federal authority chooses club membership optimally, given that national governments have chosen their fiscal policies cooperatively. Note that this solution coincides with the solution without national governments; i.e. the case in which a world central planner chooses both national policies and club membership. That is, the case in which we choose $\theta$ and

\footnotetext{
${ }^{31}$ Recall from (5d)-(5e) that $k=e-\frac{1}{(1-\theta) A}$ is the tax base in each country in a symmetric equilibrium. If $\gamma=0$, i.e. the services of the public good do not extend beyond national boundaries or,
} 
$M$ simultaneously to maximize the representative member's utility (1) subject to the world competitive equilibrium (8a)-(8c). ${ }^{32}$ This is the socially optimum.

\section{3 Main result}

It remains to compare the equilibrium solution $(\tilde{\theta}, \tilde{M})$ given by (6) and (9) with the benchmark, efficient solution $\left(\theta^{*}, M^{*}\right)$ given by (7) and (10). Details are in the Appendix. Here, we summarize results in the following proposition:

Proposition 2: In equilibrium, both union membership and national income tax rates are inefficiently low relative to the benchmark case in which union membership is chosen subject to cooperative national policies. Thus, $\tilde{M}<M^{*}$ and $\widetilde{\theta}<\theta^{*}$.

\section{Proof: See Appendix.}

Intuitively, when national policies are decentralized, there are inefficiencies that increase with the size of population (see Proposition 1 above). Hence, when the federal authority chooses club membership, it finds it optimal to choose a relatively small membership so as to reduce the magnitude of Nash-type inefficiencies.

\section{4 Numerical results}

Numerical simulations confirm the above analytical result. ${ }^{33}$ We start by choosing the parameter values $\gamma=0.5, \lambda=0.5, v=1.2, \beta=0.2, A=2, e=10$. Then, the system (6) and (9) gives $\widetilde{\theta}=0.37$ and $\tilde{M}=1.28$ for the equilibrium case, while the system (7) and (10) gives $\theta^{*}=0.77$ and $M^{*}=14.45$ for the efficient case. This is as predicted in Proposition 2.

Changes in parameter values give intuitive results. For instance, when the external cross-border, or scale, effect (as measured by the parameter $\gamma$ in equation (5f) above) increases, union membership increases in both the equilibrium solution

equivalently, there are no scale effects, the marginal benefit is zero.

${ }^{32}$ This is as in the basic model of clubs. That is, subject to the tradeoff between scale effects and congestion costs, a planner chooses the club size and the quantity of the public good to maximize the representative member's utility.

${ }^{33}$ We use Scientific Workplace version 3.00. We report meaningful solutions only. For instance, we do not report solutions for the tax rate which are higher than one, or solutions for membership which are less than one. 
and the efficient case. In particular, if $\gamma$ increases from 0.5 to 0.7 (the other parameter values remain as before), the above solutions change to $\widetilde{\theta}=0.30$ and $\tilde{M}=1.68$, while $\theta^{*}=0.77$ and $M^{*}=20.25$.

When congestion costs (as measured by the parameter $\lambda$ in (1) above) fall, union membership again increases. In particular, if $\lambda$ falls from 0.5 to 0.2 (the other parameter values are as in the first example above), we get $\widetilde{\theta}=0.35$ and $\tilde{M}=1.32$, while $\theta^{*}=0.77$ and $M^{*}=36.16$. Notice the big rise in $M^{*}$ (from 14.45 to 36.16 ) in the efficient case. An increase in the value given to the international public good (as measured by the parameter $v$ in (1) above) gives similar results. In particular, if $v$ increases from 1.2 to 1.5 , we get $\widetilde{\theta}=0.47$ and $\tilde{M}=1.46$, while $\theta^{*}=0.77$ and $M^{*}=18.07$.

When capital mobility costs (as measured by the parameter $\beta$ ) fall, the efficient solution is unaffected (as shown in (7) above), while the equilibrium union membership, $\tilde{M}$, decreases. In particular, if $\beta$ falls from 0.2 to 0.1 (the other parameter values are as in the first example above), we get $\widetilde{\theta}=0.43$ and $\tilde{M}=1.1$. That is, when $\beta$ falls, $\tilde{M}$ shifts further away from $M^{*}$. Intuitively, the inefficiency being associated with tax competition for internationally mobile tax bases - gets worse when capital mobility or the size of population increases. Hence, when $\beta$ falls, the federal authority finds it optimal to set an even smaller membership to mitigate the adverse consequences of higher tax competition. Therefore, union membership should decrease with any factors that exacerbate Nash-type inefficiencies; growing capital mobility is one such factor.

It is important to point out that the value of equilibrium membership, $\tilde{M}$, is just above one in all numerical solutions. This is robust to changes in parameter values (for instance, this is the case even in the presence of strong scale effects, i.e. relatively high values of $\gamma) .^{34}$ That is, the costs of decentralized policymaking dominate, and these costs begin to take place on the very first unit. Hence, under tax competition and free riding, the precondition for union creation, not to mention union enlargement, is coordination of national tax policies. 


\section{CONCLUSIONS AND POLICY IMPLICATIONS}

This paper has studied the endogenous determination of club membership, when national fiscal policies are uncoordinated. The setup was a multi-country general equilibrium model with international capital movements and public goods with cross-border externalities. In choosing club membership, the federal authority, or equivalently the individual voter, had the ability to internalize externalities and reduce the inefficiencies arising from uncoordinated national fiscal policies.

We showed that equilibrium membership decreases with any factors that generate or exacerbate Nash-type inefficiencies. In the particular case in which these inefficiencies take the form of tax competition and free riding, one can rationalize the formation of very small economic unions only.

The normative lesson is that the precondition for a bigger EU is intergovernmental cooperation. Cooperation at supranational or federal level is not enough to rationalize the enlargement process. The same is true for factors like increasing scale effects, falling congestion costs, etc. These factors can play a role in justifying a bigger EU, only if countries in Europe start cooperating their tax policies.

We believe that our results imply "a policy trilemma": high degrees of international economic integration (here, in the form of international capital movements and international public goods), national autonomy (here, in the form of decentralized national tax policies) and union enlargement (here, in the form of an increase in union membership) are difficult to co-exist. One has to reduce the degree of one of these three things. These results are consistent with Rodrik's (2000) argument that economic integration, nation-state policies and mass politics cannot coexist. They also resemble the well-known monetary policy trilemma: perfect capital mobility, independent monetary policy and fixed exchange rates cannot co-exist.

\section{COMPARISON WITH THE LITERATURE}

Our work is directly related to two strands of literature. First, there is the literature on fiscal federalism, which has shown that, whenever cross-country spillovers exist and policies are chosen independently by each country, centralized mechanisms should be designed to correct Nash-type inefficiencies. In principle,

\footnotetext{
${ }^{34} \mathrm{We}$ have experimented with additional scale effects, for instance in the factor productivity $A$, as in
} 
federal or supranational policy is one of them [see e.g. Persson and Tabellini (1995), Inman and Rubinfeld (1996) and Oates (1999) for surveys]. In our paper, the federal policy instrument is the size of club.

Second, there is the theory of clubs. In the basic model of clubs, as said in the Introduction above, there is a tradeoff between economies of scale in the provision of public goods against congestion costs; subject to this tradeoff in the size of population, a planner chooses the optimal membership to maximize the utility of representative club member. The recent literature on the optimal number of nations has studied mixed clubs [see, among others, Bolton and Roland (1997), Alesina and Spolaore (1997), Alesina et al. (2000), Perroni and Scharf (2001), Casella (2001) and Alesina et al. (2001)]. In this literature, the key tradeoff in the size of population is between internalization of spillovers and heterogeneity in larger populations. Specifically, a larger population implies lower per capita costs of excludable public goods, but a larger distance between individual preferences and the group's choice of the public good. In turn, this tradeoff determines the optimal number of nations. ${ }^{35}$

Here, we have built on the basic model of clubs to study how the determination of union formation is also affected by members' (cooperative or noncooperative) behavior in general, and the way national tax policies are set in particular. That is, the emphasis has been on the implications of uncoordinated actions among the members.

As Cornes and Sandler (1996, p. 355-6) point out, the early literature on clubs was not always clear as to whether an equilibrium, or an optimum, club membership was analyzed. For instance, in the basic model of clubs, all decisions are modeled as a cooperative action, so that the outcome is a Pareto optimum for the members. A

\footnotetext{
Backus et al. (1992). The main results do not change. That is, $\tilde{M}$ remains tied to one.

${ }^{35}$ In Bolton and Roland (1997), the key tradeoff is between the cost of separation and the benefit from separation due to the fact that independent decision-making yields policies closer to the preferences of national voters. If there is also capital mobility, there is an additional cost in the case of separation due to tax competition. The question is whether two pre-existing regions will choose to unite or separate. In Alesina and Spolaore (1997), the key tradeoff in the size of nations is between the falling costs of the public good provided and the fact that, as a nation gets larger, the "distance" of people from their government increases. Now there are no pre-existing nations, and the question is the optimal number of nations (like in our paper). In Alesina et al. (2000), there is a tradeoff between the higher cost associated with an increase in the size and number of countries and the gains from more available resources. In Perroni and Scharf (2001), the tradeoff is between economies of scale in public good provision and the need to provide public goods tailored to different tastes, and how this tradeoff is affected by tax competition. In Casella (2001), a larger coalition implies lower per capita taxes but a larger distance between the group's choice of the public good and individuals' preferred option. In Alesina et al. (2001), the tradeoff is between taking decision in common and heterogeneous preferences. They model union formation in two stages (first creation and then enlargement).
} 
notable exception in the early literature, that did study uncoordinated behavior on the part of members and hence non-optimum membership, was Scotchmer (1985). ${ }^{36}$

The recent literature on the optimal number of nations has studied noncooperative game representations of club formation and has distinguished between optimal and equilibrium membership (see footnote 13 above). However, in most of this literature, club membership has been determined residually by, for instance, nonnegative profit conditions [see e.g. Scotchmer (1985)], incentive participation constraints [see e.g. Alesina et al. (2001)], or individuals arranging themselves into jurisdictions [see e.g. Perroni and Scharf (2001)]. In our paper, by contrast, membership is chosen optimally at federal level. This is important because our hierarchical structure allows federal policy to internalize the behavior of national governments and hence reduce the inefficiencies arising from uncoordinated national policies. This is then reflected into equilibrium membership.

Therefore, the main difference of our work is that we study how Nash inefficiencies, arising from decentralized national fiscal policies, affect the tradeoff in the size of population and how this affects the choice of club membership. We also addressed these issues in a general equilibrium model with international capital mobility and international public goods.

\section{LIMITATIONS AND EXTENSIONS}

We close with limitations and possible extensions. First, we showed that, in the presence of international capital mobility and international public goods, one can rationalize the formation of very small economic unions only. If this is the case, a natural question to ask is "how can equilibrium membership, $\tilde{M}$, increase, when national governments still play the nationalistic (Nash) game?". One way could be to add new spillover effects, which generate negative externalities that counter-balance the positive externalities generated by international capital movements and international public goods. Such offsetting effects could possibly leave room for manoeuvre and allow $\tilde{M}$ to un-stick away from one. One such spillover effect can be generated by state-contingent redistributive cross-country transfers, like those implied by EU structural funds [see Park and Philippopoulos (2003)]. We have experimented

\footnotetext{
${ }^{36}$ For a survey of this part of the early literature, see Cornes and Sandler (1996, chapter 14.4).
} 
with a richer setup that includes transfers that redistribute from the relatively rich to the relatively poor countries. We report that indeed in this case $\tilde{M}$ is higher than one. However, our main result does not change; namely, it is optimal to choose a relatively small membership in order to reduce the magnitude of Nash-type problems.

Second, we assumed that policymakers (national and supra-national) are benevolent. In the real world, policymakers have their own policy agendas that do not necessarily coincide with those of private agents. For instance, national policymakers can be driven by electoral or partisan motives, while federal bureaucrats might seek a larger budget and hence more influence. However, we believe that any additional inefficiency at national level (e.g. in the form of self-interested local politicians) will strengthen our main result. On the other hand, the effect of size-seeking supranational bureaucrats will naturally lead to higher equilibrium membership (this can already be captured by a smaller value of $\lambda$ in our model; see the numerical results in section IV). Anyway, here we assumed benevolent policymakers because we wanted to focus on how the lack of cooperation between member countries affects union formation.

Third, here we focused on the case in which countries are alike in equilibrium. Since our aim was to study how incentives affect union membership, this is not restrictive. Also, our work can serve as a useful benchmark. At this stage, we can only speculate what happens in the case countries differ ex post. Inefficiencies and problems associated with decentralized nationalistic policies are logically expected to deteriorate when countries are asymmetric. If this is the case, our main result should again go through (i.e. that $\tilde{M}$ is inefficiently low). On the other hand, we know that the very justification of centralized policies is disputable when heterogeneities are important, simply because the costs of uniform policies increase with heterogeneity.

Fourth, we did not study stability of the club. We just studied its creation (see footnote 16). It is known that coalitions, once formed, can be stable or unstable depending on whether members and non-members have an incentive to move or trade places [see e.g. Cornes and Sandler (1996) for the general theory of clubs; see e.g. Burbidge et al. (1997) and Alesina et al. (2001) for the literature on the optimal number of nations]. Stability depends heavily on the type of cross-border policy externalities [see e.g. Yi (1997)], as well as the number of member countries since an increase in the size of population increases the complexity of negotiations and coalition stability. 


\section{APPENDIX}

\section{Proof of Result 1:}

Consider equation (6) in the text. Define the left-hand side, $L H S \equiv A\left(e-\frac{1}{(1-\theta) A}\right)>0, \quad$ and the right-hand side, $R H S \equiv v\left[A\left(e-\frac{1}{(1-\theta) A}\right)-\frac{\theta}{(1-\theta)^{2}}-\frac{2 A^{2} \theta(M-1)(1-\gamma)}{\beta}\right]>0$, where LHS $=R H S$.

Then,

$$
L H S_{\theta}=-\frac{1}{(1-\theta)^{2}}<0
$$

and $R H S_{\theta}=-v\left[\frac{1}{(1-\theta)^{2}}+\frac{1+\theta}{(1-\theta)^{3}}+\frac{2 A^{2}(M-1)(1-\gamma)}{\beta}\right]<0 . \quad$ Also, for $\quad 0<\theta<1$, $\left|R H S_{\theta}\right|>\left|L H S_{\theta}\right|$ from the second-order condition of the maximization problem. Hence, assuming existence of a $0<\theta<1,{ }^{37}$ there is a unique solution for the Nash tax rate, $\widetilde{\theta}$, as shown in Figure 1 below. In turn, total differentiation in (6) implies $\frac{\partial \widetilde{\theta}}{\partial M}=\frac{-v 2 A^{2} \theta(1-\gamma)}{\beta\left(L H S_{\theta}-R H S_{\theta}\right)}$, which is negative because $L H S_{\theta}-R H S_{\theta}>0$. The other comparative static results follow easily.

Figure 1 here

\section{Proof of Result 2:}

Consider equation (7) in the text. Define the left-hand side, $L H S \equiv A\left(e-\frac{1}{(1-\theta) A}\right)>0, \quad$ and the right-hand side, $R H S \equiv v[1+\gamma(M-1)]\left[A\left(e-\frac{1}{(1-\theta) A}\right)-\frac{\theta}{(1-\theta)^{2}}\right]>0$, where LHS $=R H S$. Then, $L H S_{\theta}=-\frac{1}{(1-\theta)^{2}}<0$ and $R H S_{\theta}=-v[1+\gamma(M-1)]\left[\frac{1}{(1-\theta)^{2}}+\frac{1+\theta}{(1-\theta)^{3}}\right]<0$. Also, for $0<\theta<1,\left|R H S_{\theta}\right|>\left|L H S_{\theta}\right|$ from the second-order condition of the maximization

\footnotetext{
${ }^{37}$ In particular, existence requires that the parameter values satisfy that for $\theta=0, R H S>L H S$; and for $\theta \rightarrow 1, R H S<L H S$.
} 
problem. Hence, assuming existence of a $0<\theta<1$, there is a unique solution for the cooperative tax rate, $\theta^{*}$, as shown in Figure 1 above. The same figure also shows that $0<\widetilde{\theta}<\theta^{*}<1$; this happens because the RHS in the cooperative case is always larger than the RHS in the Nash case, while the LHS is the same in both cases. In turn, total differentiation in (7) implies $\frac{\partial \theta^{*}}{\partial M}=\frac{v \gamma\left[A\left(e-\frac{1}{(1-\theta) A}\right)-\frac{\theta}{(1-\theta)^{2}}\right]}{\left(L H S_{\theta}-R H S_{\theta}\right)}$, which is positive because $\left[A\left(e-\frac{1}{(1-\theta) A}\right)-\frac{\theta}{(1-\theta)^{2}}\right]>0$ and $L H S_{\theta}-R H S_{\theta}>0$. The other comparative static results follow easily.

\section{Proof of Proposition 2:}

We will solve equations (6) and (9) for $\widetilde{\theta}$ and $\tilde{M}$, and equations (7) and (10) for $\theta^{*}$ and $M^{*}$.

It is convenient to start by comparing (6) and (7). When $M=1,(6)$ and (7) coincide so that $\widetilde{\theta}=\theta^{*}$ (note that, when $M=1$, we have to set $v>1$ for a solution to exist). Then, for $M>1, \theta$ and $M$ move in opposite directions along (6) (see Result 1), while $\theta$ and $M$ move in the same direction along (7) (see Result 2). This is shown in Figure 2a below.

Figure 2a here

Compare now (9) and (10). When $M=1$, (9) and (10) coincide. Then, for $M>1, \quad \theta$ and $M$ move in the same direction along (10); this is because $\left[A\left(e-\frac{1}{(1-\theta) A}\right)-\frac{\theta}{(1-\theta)^{2}}\right]>0$. On the other hand, (9) lies to the left of (10) as shown in Figure $2 \mathrm{~b}$ below; this is because, for any given $M, \theta^{*}>\widetilde{\theta}$.

Figure $2 b$ here

We will now combine results to get solutions for $(\tilde{\theta}, \tilde{M})$ and $\left(\theta^{*}, M^{*}\right)$. If these solutions exist, they are shown in Figure 2c below. 
Figure 2c here

In figure 2c, the intersection(s) of (7) and (10), i.e. point $C$, lies above and to the right of the intersection(s) of (6) and (9), i.e. point $N$. This is for the following reason: As shown in figure $2 \mathrm{c}$, if there is an equilibrium (i.e. if (6) and (9) on the one hand, and (7) and (10) on the other hand, intersect), $\theta^{*}$ should lie to the right of $\widetilde{\theta}$. The question is what is the relation between $M^{*}$ and $\tilde{M}$. Now notice that the marginal benefit of $M$ (see the left-hand sides of (9) and (10)) is increasing in $\theta$; specifically, differentiating the marginal benefit with respect to $\theta$, we get $v \gamma\left[A\left(e-\frac{1}{(1-\theta) A}\right)-\frac{\theta}{(1-\theta)^{2}}\right]$, which is positive in both the non-cooperative and cooperative case. Therefore, since $\theta^{*}>\widetilde{\theta}$, the left-hand side of (10) is higher than the left-hand side of (9). But then the right-hand side of (10) is also higher than the righthand side of (9). In other words, $\lambda M^{*}>\lambda \tilde{M}+$ a positive term. This can hold only if $M^{*}>\tilde{M}$. Therefore, $\theta^{*}>\widetilde{\theta}$ and $M^{*}>\tilde{M}$. 


\section{REFERENCES}

Alesina A., R. Perotti and E. Spolaore (1995): Together separately? Issues on the costs and benefits of political and fiscal unions, European Economic Review, 39, 751-758.

Alesina A. and E. Spolaore (1997): On the number and size of nations, Quarterly Journal of Economics, 112, 1027-1056.

Alesina A., E. Spolaore and R. Wacziarg (2000): Economic integration and political disintegration, American Economic Review, 90, 1276-1296.

Alesina A. and R. Wacziarg (1999): Is Europe going too far? Carnegie-Rochester Conference Papers on Public Policy, 51, 1-42.

Alesina A., I. Angeloni and F. Etro (2001): The political economy of international unions, NBER Working Paper, no. 8645.

Alesina A., I. Angeloni and L. Schuknecht (2001): What does the European Union do?, Mimeo, Harvard University and European Central Bank.

Backus D., P. Kehoe and T. Kehoe (1992): In search of scale effects in trade and growth, Journal of Economic Theory, 58, 377-409.

Bjorvatn K. and G. Schjelderup (2000): Tax competition and international public goods, CESifo Working Paper, no. 390, Munich.

Bolton P. and G. Roland (1997): The breakup of nations: A political economy analysis, Quarterly Journal of Economics, 112, 1057-90.

Bolton P., G. Roland and E. Spolaore (1996): Economic theories of the breakup and integration of nations, European Economic Review, 40, 697-705.

Burbidge J., J. DePater, G. Myers and A. Sengupta (1977): A coalition-formation approach to equilibrium federations and trading blocks, American Economic Review, 87, 940-56.

Caplan A., R. Cornes and E. Silva (2000): Pure public goods and income redistribution in a federation with decentralized leadership and imperfect labor mobility, Journal of Public Economics, 77, 265-284.

Casella A. and B. Frey (1992): Federalism and clubs, European Economic Review, 36, 639-646.

Casella A. (2001): The role of market size in the formation of jurisdictions, Review of Economic Studies, 68, 83-108.

Cooper R. and A. John (1988): Coordinating coordination failures in Keynesian models, Quarterly Journal of Economics, CIII, 441-463. 
Cornes R. and T. Sandler (1996): The Theory of Externalities, Public Goods and Club Goods. Second edition. Cambridge University Press, Cambridge.

Devereux M., B. Lockwood and M. Redoano (2002): Do countries compete over corporate tax rates?, CSGR Working Paper, no. 97/02, University of Warwick.

Drazen A. (2000): Political Economy in Macroeconomics. Princeton University Press, Princeton, New Jersey.

Inman R. and D. Rubinfeld (1996): Designing tax policy in federalist economies: An overview, Journal of Public Economics, 60, 307-334.

Inman R. and D. Rubinfeld (1997): The political economy of federalism, in Perspectives on Public Choice, edited by D. Mueller. Cambridge University Press, New York.

Inman R. and D. Rubinfeld (2002): Subsidiarity, governance and EU economic policy, CESifo Forum, 3, no. 4, 3-11.

Kehoe P. (1987): Coordination of fiscal policies in a world economy, Journal of Monetary Economics, 19, 349-376.

Kehoe P. (1989): Policy cooperation among benevolent governments may be undesirable, Review of Economic Studies, 56, 289-296.

Laffont J.-J. and J. Tirole (1998): A Theory of Incentives in Procurement and Regulation. The MIT Press, Cambridge, Mass.

Mueller D. (1989): Public Choice II. Cambridge University Press, Cambridge.

Myles G. (1995): Public Economics. Cambridge University Press, Cambridge.

Oates W. (1999): An essay on fiscal federalism, Journal of Economic Literature, 37, 1120-1149.

Park H. and A. Philippopoulos (2003): On the dynamics of growth and fiscal policy with redistributive transfers, Journal of Public Economics, 87, 515-538.

Perotti R. (2001): Is a uniform social policy better? Fiscal federalism and factor mobility, American Economic Review, 91, 596-610.

Perroni C. and K. Scharf (2001): Tiebout with politics: capital tax competition and constitutional choices, Review of Economic Studies, 68, 133-154.

Persson T. and Tabellini G. (1992): The politics of 1992: Fiscal policy and European integration, Review of Economic Studies, 59, 689-701.

Persson T. and G. Tabellini (1995): Double-edged incentives: Institutions and policy coordination, in Handbook of International Economics, vol. 3, edited by G. Grossman and K. Rogoff. North-Holland. Amsterdam. 
Persson T. and G. Tabellini (1996): Federal fiscal constitutions: risk sharing and moral hazard, Econometrica, 64, 623-646.

Philippopoulos A. and G. Economides (2003): Are Nash tax rates too low or too high? The role of endogenous growth in models with public goods, Review of Economic Dynamics, 6, 37-53.

Razin A. and Sadka E., editors, (1999): The Economics of Globalization: Policy Perspectives from Public Economics, Cambridge University Press, Cambridge.

Rodrik D. (2000): How far will international economic integration go? Journal of Economic Perspectives, 14, 177-186.

Scotchmer S. (1985): Profit maximizing clubs, Journal of Public Economics, 27, $25-$ 45.

Sorensen P. B. (2000): The case of international tax coordination reconsidered, Economic Policy, 31, 429-472.

Yi S. S. (1997): Stable coalition structures with externalities, Games and Economic Behavior, 20, 201-237. 
Figure 1

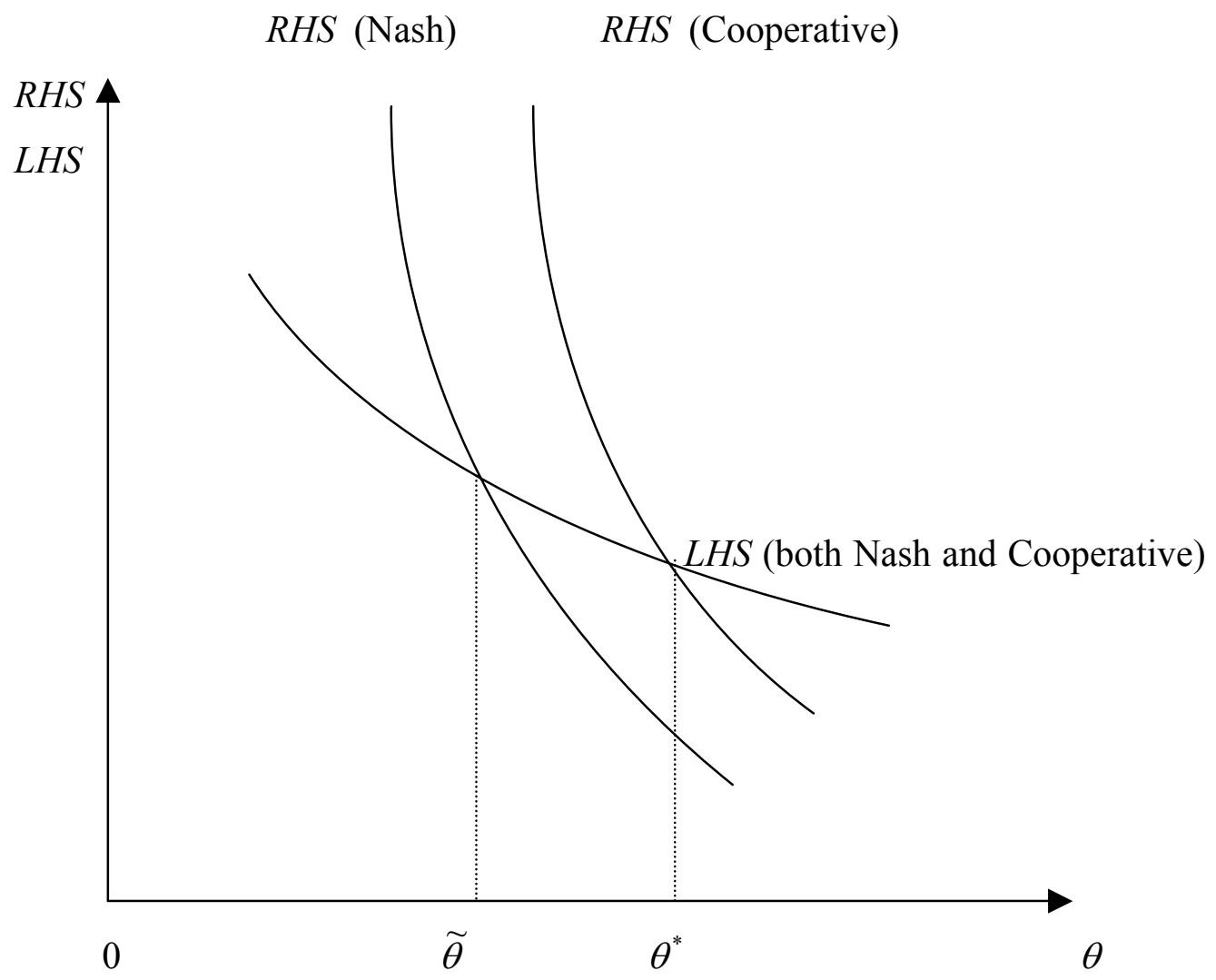


Figure 2a
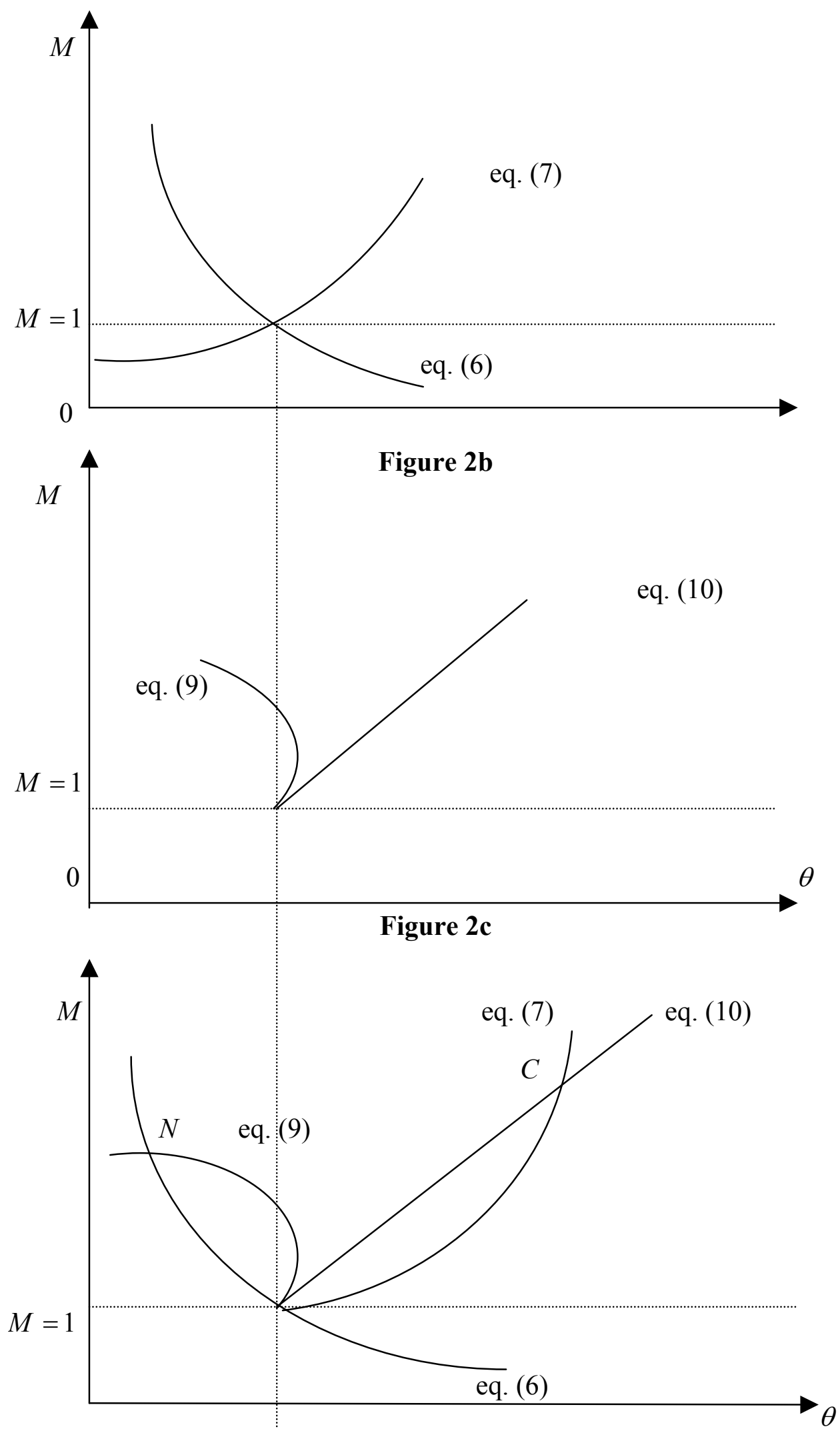


\title{
CESifo Working Paper Series
}

\author{
(for full list see www.cesifo.de)
}

920 Klaus Wälde, Endogenous Business Cycles and Growth, April 2003

921 Ramon Castillo and Stergios Skaperdas, All in the Family or Public? Law and Appropriative Costs as Determinants of Ownership Structure, April 2003

922 Peter Fredriksson and Bertil Holmlund, Improving Incentives in Unemployment Insurance: A Review of Recent Research, April 2003

923 Bernard M.S. van Praag and Adam S. Booij, Risk Aversion and the Subjective Time Discount Rate: A Joint Approach, April 2003

924 Yin-Wong Cheung, Kon S. Lai, and Michael Bergman, Dissecting the PPP Puzzle: The Unconventional Roles of Nominal Exchange Rate and Price Adjustment, April 2003

925 Ugo Trivellato and Anna Giraldo, Assessing the 'Choosiness' of Job Seekers. An Exploratory Approach and Evidence for Italy, April 2003

926 Rudi Dornbusch and Stanley Fischer, International Financial Crises, April 2003

927 David-Jan Jansen and Jakob de Haan, Statements of ECB Officials and their Effect on the Level and Volatility of the Euro-Dollar Exchange Rate, April 2003

928 Mario Jametti and Thomas von Ungern-Sternberg, Assessing the Efficiency of an Insurance Provider - A Measurement Error Approach, April 2003

929 Paolo M. Panteghini and Guttorm Schjelderup, Competing for Foreign Direct Investments: A Real Options Approach, April 2003

930 Ansgar Belke, Rainer Fehn, and Neil Foster, Does Venture Capital Investment Spur Employment Growth?, April 2003

931 Assar Lindbeck, Sten Nyberg, and Jörgen W. Weibull, Social Norms and Welfare State Dynamics, April 2003

932 Myrna Wooders and Ben Zissimos, Hotelling Tax Competition, April 2003

933 Torben M. Andersen, From Excess to Shortage - Recent Developments in the Danish Labour Market, April 2003

934 Paolo M. Panteghini and Carlo Scarpa, Irreversible Investments and Regulatory Risk, April 2003 
935 Henrik Jacobsen Kleven and Claus Thustrup Kreiner, The Marginal Cost of Public Funds in OECD Countries. Hours of Work Versus Labor Force Participation, April 2003

936 Klaus Adam, George W. Evans, and Seppo Honkapohja, Are Stationary Hyperinflation Paths Learnable?, April 2003

937 Ulrich Hange, Education Policy and Mobility: Some Basic Results, May 2003

938 Sören Blomquist and Vidar Christiansen, Is there a Case for Public Provision of Private Goods if Preferences are Heterogeneous? An Example with Day Care, May 2003

939 Hendrik Jürges, Kerstin Schneider, and Felix Büchel, The Effect of Central Exit Examinations on Student Achievement: Quasi-experimental Evidence from TIMSS Germany, May 2003

940 Samuel Bentolila and Juan F. Jimeno, Spanish Unemployment: The End of the Wild Ride?, May 2003

941 Thorsten Bayindir-Upmann and Anke Gerber, The Kalai-Smorodinsky Solution in Labor-Market Negotiations, May 2003

942 Ronnie Schöb, Workfare and Trade Unions: Labor Market Repercussions of Welfare Reform, May 2003

943 Marko Köthenbürger, Tax Competition in a Fiscal Union with Decentralized Leadership, May 2003

944 Albert Banal-Estañol, Inés Macho-Stadler, and Jo Seldeslachts, Mergers, Investment Decisions and Internal Organisation, May 2003

945 Kaniska Dam and David Pérez-Castrillo, The Principal-Agent Matching Market, May 2003

946 Ronnie Schöb, The Double Dividend Hypothesis of Environmental Taxes: A Survey, May 2003

947 Erkki Koskela and Mikko Puhakka, Stabilizing Competitive Cycles with Distortionary Taxation, May 2003

948 Steffen Huck and Kai A. Konrad, Strategic Trade Policy and Merger Profitability, May 2003

949 Frederick van der Ploeg, Beyond the Dogma of the Fixed Book Price Agreement, May 2003

950 Thomas Eichner and Rüdiger Pethig, A Microfoundation of Predator-Prey Dynamics, May 2003

951 Burkhard Heer and Bernd Süssmuth, Cold Progression and its Effects on Income Distribution, May 2003 
952 Yu-Fu Chen and Michael Funke, Labour Demand in Germany: An Assessment of NonWage Labour Costs, May 2003

953 Hans Gersbach and Hans Haller, Competitive Markets, Collective Decisions and Group Formation, May 2003

954 Armin Falk, Urs Fischbacher, and Simon Gächter, Living in Two Neighborhoods Social Interactions in the LAB, May 2003

955 Margarita Katsimi, Training, Job Security and Incentive Wages, May 2003

956 Clemens Fuest, Bernd Huber, and Jack Mintz, Capital Mobility and Tax Competition: A Survey, May 2003

957 Edward Castronova, The Price of 'Man' and 'Woman': A Hedonic Pricing Model of Avatar Attributes in a Synthetic World, June 2003

958 Laura Bottazzi and Marco Da Rin, Financing Entrepreneurial Firms in Europe: Facts, Issues, and Research Agenda, June 2003

959 Bruno S. Frey and Matthias Benz, Being Independent is a Great Thing: Subjective Evaluations of Self-Employment and Hierarchy, June 2003

960 Aaron Tornell and Frank Westermann, Credit Market Imperfections in Middle Income Countries, June 2003

961 Hans-Werner Sinn and Wolfgang Ochel, Social Union, Convergence and Migration, June 2003

962 Michael P. Devereux, Measuring Taxes on Income from Capital, June 2003

963 Jakob de Haan, Jan-Egbert Sturm and Bjørn Volkerink, How to Measure the Tax Burden on Labour at the Macro-Level?, June 2003

964 Harry Grubert, The Tax Burden on Cross-Border Investment: Company Strategies and Country Responses, June 2003

965 Kirk A. Collins and James B. Davies, Measuring Effective Tax Rates on Human Capital: Methodology and an Application to Canada, June 2003

966 W. Steven Clark, Using Micro-Data to Assess Average Tax Rates, June 2003

967 Christopher Heady, The 'Taxing Wages' Approach to Measuring the Tax Burden on Labour, June 2003

968 Michael P. Devereux and Alexander Klemm, Measuring Taxes on Income from Capital: Evidence from the UK, June 2003

969 Bernhard Eckwert and Itzhak Zilcha, The Effect of Better Information on Income Inequality, June 2003 
970 Hartmut Egger and Josef Falkinger, The Role of Public Infrastructure for Firm Location and International Outsourcing, June 2003

971 Dag Morten Dalen and Trond E. Olsen, Regulatory Competition and Multi-national Banking, June 2003

972 Matthias Wrede, Tax Deductibility of Commuting Expenses and Residential Land Use with more than one Center, June 2003

973 Alessandro Cigno and Annalisa Luporini, Scholarships or Student Loans? Subsidizing Higher Education in the Presence of Moral Hazard, June 2003

974 Chang Woon Nam, Andrea Gebauer and Rüdiger Parsche, Is the Completion of EU Single Market Hindered by VAT Evasion?, June 2003

975 Michael Braulke and Giacomo Corneo, Capital Taxation May Survive in Open Economies, July 2003

976 Assar Lindbeck, An Essay on Welfare State Dynamics, July 2003

977 Henrik Jordahl and Luca Micheletto, Optimal Utilitarian Taxation and Horizontal Equity, July 2003

978 Martin D. D. Evans and Richard K. Lyons, Are Different-Currency Assets Imperfect Substitutes?, July 2003

979 Thorsten Bayindir-Upmann and Frank Stähler, Market Entry Regulation and International Competition, July 2003

980 Vivek Ghosal, Firm and Establishment Volatility: The Role of Sunk Costs, Profit Uncertainty and Technological Change, July 2003

981 Christopher A. Pissarides, Unemployment in Britain: A European Success Story, July 2003

982 Wolfgang Buchholz, Richard Cornes, and Wolfgang Peters, On the Frequency of Interior Cournot-Nash Equilibria in a Public Good Economy, July 2003

983 Syed M. Ahsan and Panagiotis Tsigaris, Choice of Tax Base Revisited: Cash Flow vs. Prepayment Approaches to Consumption Taxation, July 2003

984 Campbell Leith and Jim Malley, A Sectoral Analysis of Price-Setting Behavior in US Manufacturing Industries, July 2003

985 Hyun Park and Apostolis Philippopoulos, Choosing Club Membership under Tax Competition and Free Riding, July 2003 